\title{
Congressional Fellow Brian Holloway Illuminates Materials Issues in Washington Policy
}

"The issues never change in Washington, just the players," is a common adage among Washington politicians; however, Brian Holloway, the 1997-1998 Materials Research Society/Optical Society of America Congressional Science and Engineering Fellow, has found that he is about the only new staff member working for Senator John D. Rockefeller (DWV). Holloway said, "Staff turnaround time on Capitol Hill of six months to two years is not uncommon. Most of Senator Rockefeller's staff members have been with him more than five years. Some have been with him since he was governor in West Virginia and several have been with him since he became a U.S. senator." This benefits Holloway as a science staff member since his co-workers know the history of Rockefeller's legislative issues and maintain an "institutional memory of personal contacts." Holloway said that Rockefeller's staff will be able to continue the projects Holloway is unable to complete during his one-year tenure.

On state-level issues, Holloway attended a conference in West Virginia focused on "industries of the future," a program in the Office of Industrial Technology (OIT) within the U.S. Department of Energy (DOE). West Virginian industries gathered to define important technology-based problems that DOE research programs could help solve. Holloway looked for possible cooperative agreements between the industries and government. According to Holloway, the glass industry needs help maintaining the refractories, and the aluminum industry needs materials related to processing such as new nanomaterials and new cathode materials. The steel industry, along with aluminum and glass, needs new materials for sensor technology in order to place in situ sensors in extremely harsh environments.

According to Holloway, Senator Rockefeller uses his international clout to bring in industry to help build the economy in West Virginia. In January, the Senator oversaw three agreements between companies in West Virginia and Taiwan. CEL Technologies, Inc. (West Virginia) and Ta-Yih Industries (Taiwan) created an international company, CELTI (CEL Technologies International), to manufacture solid-state ceramic lighting (SSCL) in West Virginia. SSCL is produced by covering a thin, low-carbon steel with layers of ceramic material. After being coated and processed in a ceramic oven, the surface projects a uniform illumination, eliminat-

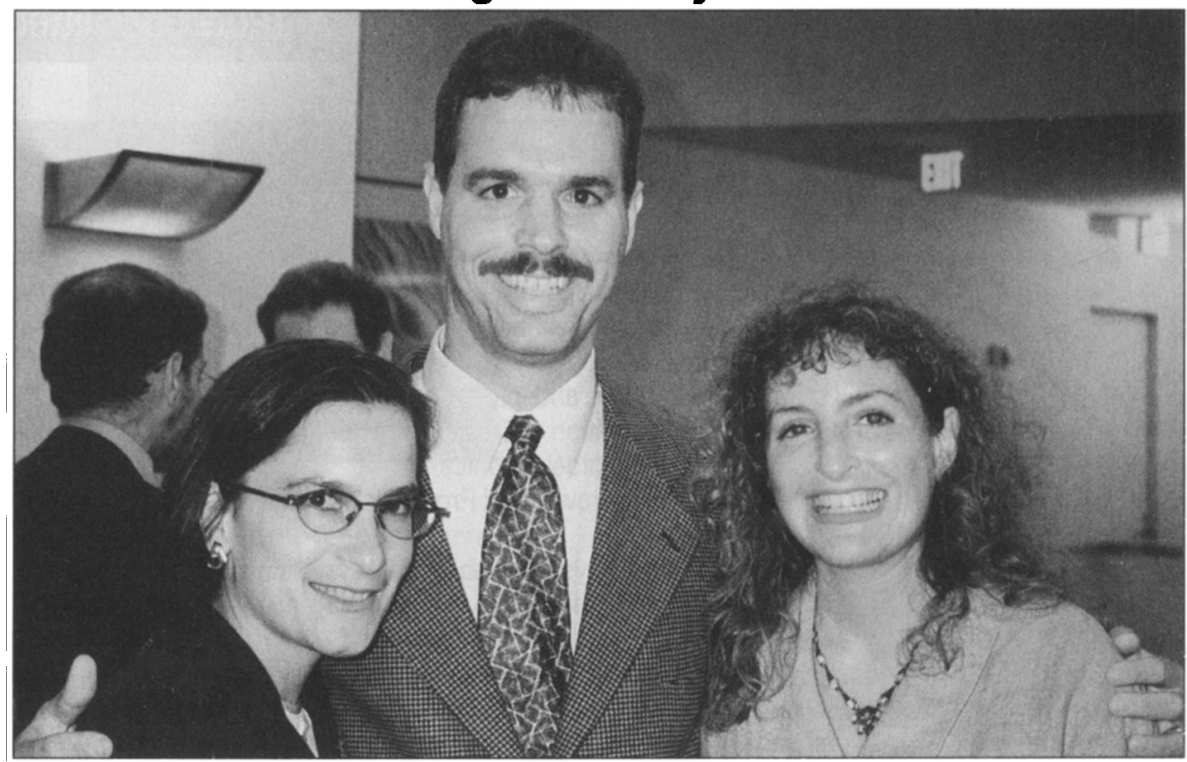

(Left to right): Materials Research Society/Optical Society of America Congressional Science and Engineering Fellows Kelly Kirkpatrick (1995-1996), Brian Holloway (1997-1998), and Michal Freedhoff (1996-1997) meet at the American Association for the Advancement of Science (AAAS) Congressional Fellowship Reception in Washington, DC in September 1997.

ing "hot spots" often found in background lighting. TFX Equities (United States) and TLM Aerospace, Inc. (Taiwan) have signed a joint venture agreement to build a TLM facility in West Virginia. This new plant will build two models of a single-engine, four-passenger aircraft. Third, Toyota Motor Corp. agreed to expand the Toyota engine plant in West Virginia. This announcement came the day after Senator Rockefeller test-drove Toyota's hybrid car, the Prius, which combines a gasoline engine with an electric motor, maximizing fuel economy.

Holloway knows that these advances in technology and manufacturing facilities would not be possible without scientific research and development (R\&D). On the federal level, Holloway's primary goal is to look for new initiatives on alternative fuel, which leads him to various materials issues. Fuel technology for coal involves catalytic activity, and alternative electricvehicle battery technology research involves electrochemical reactions as well as thin-film deposition methods.

Holloway is also working on Internet research. He said that in order to make the next generation Internet run 100-1,000 times faster than the current system, extensive materials-related research is required to achieve high-speed switching of the optical network.

On the active legislative front, Senator Rockefeller has co-sponsored legislation to make the R\&D tax credit permanent. According to Holloway, this would help materials researchers maintain healthy research programs that are partially based on the tax credit. Currently, companies must renew their $R \& D$ tax credit status every two years, which impairs the security of long-term research programs.

Holloway credits past MRS/OSA Fellows Kelly Kirkpatrick (1995-1996) and Michal Freedhoff (1996-1997) for paving the way for him in Washington. Freedhoff's electronic diary of her year as Fellow has proven invaluable to Holloway as he plows through his tenure. During Holloway's two-week orientation at the American Association for the Advancement of Science (AAAS), which coordinates the fellowship, Kirkpatrick, along with OSA past-president Duncan Moore (Assistant Director of Technology, OSTP) helped Holloway locate a congressional office to work for, and both Freedhoff and Kirkpatrick continue to provide information and ideas as Holloway pursues his projects. 